\title{
Stable Isotope Analyses in Aquatic Ecology (a review)
}

\author{
Michail I. Gladyshev* \\ Institute of Biophysics of Siberian Branch of Russian Academy of Sciences, \\ 50 Akademgorodok, Krasnoyarsk, 660036 Russia \\ Siberian Federal University \\ 79 Svobodny, Krasnoyarsk, 660041 Russia $^{1}$
}

Received 7.12.2009, received in revised form 14.12.2009, accepted 21.12.2009

\begin{abstract}
Theory and practice of analyses of stable isotopes of carbon and nitrogen for food trophic studies in aquatic ecology are regarded basing on literature, published primarily in the last decade. Methods of measuring of the stable isotope ratios, $\delta^{13} \mathrm{C}$ and $\delta^{15} \mathrm{~N}$, are described including those of compound specific isotope analyses. Differences in isotopic signatures between terrestrial and aquatic organisms as well as between taxa and life forms and habitats are generalized. Trophic fractionation of ${ }^{15} \mathrm{~N}$ as the basis of quantitative estimation of trophic positions of organisms is described. Environmental factors affecting values of isotope ratios and limitations of the stable isotope method are discussed. Novel conceptions of aquatic ecology, developed on the basis of the stable isotope analyses are listed. As concluded, the stable isotopes are becoming a standard analytical tool in food web ecology. Careful use must be made of this tool, however.
\end{abstract}

Keywords: stable isotopes, aquatic ecosystems, trophic fractionation, trophic position

\section{Introduction}

Development of methods and equipments is one of the driving forces of progress of any science. Over the past two decades stable isotope analysis (SIA) has become an important technique in ecology. Stable isotopes of elements occurring in nature often form spatial and temporal patterns in their distributions in inorganic materials which are transferred to living organisms and so can be used to track their migrations. For instance, isotopic analysis of fish otoliths could be used to document migration patterns of fish species encountering coastal marine, estuarine, river, and lake environments throughout its life cycle (Hobson, 1999). The molecular isotopic signature of environmental contaminants can allocate a contamination to a specific source in order to allow appropriate means of risk reduction and/or to identify responsible parties in litigation (Schmidt et al., 2004). Many stable isotopes, including those of metals, sulfur $\left({ }^{34} \mathrm{~S}\right)$ and deuterium can be used for above studies.

However a majority of ecologists use stable isotopes of carbon $\left({ }^{13} \mathrm{C}\right)$ and nitrogen $\left({ }^{15} \mathrm{~N}\right)$ for examining trophic interactions and elucidating energy flow pathways through food webs and ecosystems. There are two main interrelated problems, solved on the basis of SIA. Firstly, the stable isotope analysis has increasingly being used for unraveling the structure of food webs (e.g., Pel et al., 2003). Secondly, SIA is used to trace flows and to estimate the relative importance of

* Corresponding author E-mail address: glad@ibp.ru

1 (C) Siberian Federal University. All rights reserved 
autochthonous (terrestrial) versus allochthonous sources of organic carbon into aquatic food webs (e.g., Canuel et al., 1995; Cole et al., 2002). The aim of the present review is to regard the stable isotope analyses of food webs in aquatic ecosystems with emphasis on fresh waters.

\section{Methods}

For the analysis of bulk carbon and nitrogen isotopes in whole animals and tissues or in particulate organic matter, samples were combusted in a muffle furnace, and the resulting $\mathrm{N}_{2}$ and $\mathrm{CO}_{2}$ gases were analyzed by mass spectrometry (e.g., Fantle et al., 1999). Recently due to the progress of commercial instruments samples can be analyzed with a continuous flow isotope ratio mass spectrometer (CF-IRMS) directly coupled to an elemental analyzer (EA) and autosampler (e.g., Beaudoin et al., 1999). The carbon isotope composition of individual compounds, such as amino acids or fatty acids was measured routing the effluent from a gas chromatograph through a combustion interface to an isotope ratio mass spectrometer (GC/CIRMS) (Fantle et al., 1999; Schmidt et al., 2004; Pond et al., 2006; Budge et al., 2008). This limits the application range of SIA to compounds that are sufficiently volatile and thermally stable to be separated by GC. Non-volatile compounds of interest need to be derivatized prior to isotopic analysis (Schmidt et al., 2004).

Stable isotope data in all the works, cited in this review, were presented as the relative difference between ratios of heavy-to-light stable isotopes of a sample and a standard. A differential notation known as the delta $(\delta)$ notation is used to express these relative differences:

$$
\delta R(\%)=\left[R_{\text {sample }} / R_{\text {standard }}-1\right] \times 10^{3}
$$

where $R={ }^{13} \mathrm{C} /{ }^{12} \mathrm{C}$ or ${ }^{15} \mathrm{~N} /{ }^{14} \mathrm{~N} ; \delta R=\delta^{13} \mathrm{C}$ or ${ }^{15} \mathrm{~N}$ is the per mil, i.e., per thousand ( \%) deviation of that sample from the conventional international isotope standard, Vienna PeeDee Belemnite (PDB) limestone for $\delta^{13} \mathrm{C}$ and atmospheric $\mathrm{N}_{2}$ for $\delta^{15} \mathrm{~N}$. Therefore, when a sample contains a higher content of the heavier form of isotope (either ${ }^{13} \mathrm{C}$ or ${ }^{15} \mathrm{~N}$ ) than that of the corresponding standard, the $\delta$ exhibits a positive value; the converse case yields a negative value. The PDB standard, a fossil calcium carbonate that has a ${ }^{13} \mathrm{C}$ content nearly identical to that of $\mathrm{HCO}_{3}$ in the ocean (Wada, 2009), was used in all the works, cited in this review, except the early work of Fry (1988) who used Canyon Diablo Troilite.

Thus, rather than absolute values, the relative ratios are reported to allow a correction for mass-discriminating effects in a single instrument and to facilitate the comparison of published IRMS data. Only such relative isotope ratios can be determined with the required precision (Schmidt et al., 2004). The analytical precision of replicate isotopic analyses typically is from about $\pm 0.1 \%$ to $\pm 0.3 \%$ (e.g., Fry, 1988; Peterson et al., 1993; Canuel et al., 1995). Laboratory working standards can be pure tank gases or some biological materials (e.g., peach leaves, bovine liver, etc.), calibrated against standard reference materials usually produced by International Atomic Energy Agency (IAEA), such as IAEA-N1, glutamic acid and others (Fry, 1988; Persaud et al., 2009; Ventura and Jeppesen, 2009). Laboratory standards should be analyzed every dozen samples (Ventura and Jeppesen, 2009).

Sampling of abiotic and biotic components of aquatic ecosystems for the following stable isotope analyses is close to that for other biochemical assays. To measure the $\delta^{13} \mathrm{C}$ of dissolved inorganic carbon (DIC) water was filtered through fluorocarbon polymer filters of $0.45-\mu \mathrm{m}$ pore size into amber bottles fitted with gastight septa (Barnard et al., 2006). Samples for $\mathrm{C}$ isotope analysis of DIC also were taken without 
filtration and preserved by $1 \mathrm{~mL}$ of saturated $\mathrm{HgCl}_{2}$ solution per $30-\mathrm{mL}$ sample bottle (Gu et al., 2006).

Seston or particulate organic matter (POM) were pre-screened with $53-200-\mu \mathrm{m}$ net and then filtered onto precombusted $(4 \mathrm{~h}$, $500^{\circ} \mathrm{C}$ ) glass-fiber filters (usually $0.45 \mu \mathrm{m}$ ), which may be then frozen or dried at $50^{\circ} \mathrm{C}$ and stored (Fry, 1988; Canuel et al., 1995; Keough et al., 1996; O’Reilly et al., 2002). Many studies assume that algal biomass make up most of the POM pool and use the $\delta^{13} \mathrm{C}$ of POM as a proxy for algal $\delta^{13} \mathrm{C}$, but this approach is problematic in turbid systems where allochthonous matter dominates the POM pool (Van den Meersche et al., 2009). Thereby, some special approaches were used to obtain isotope signatures of POM components such as microalgae and bacteria. For instance, algae from laboratory cultures were incubated during a week in situ in regenerated cellulose dialysis tubing and then were filtered onto glass-fiber filters for isotopic analysis (Barnard et al., 2006). Isotopic signals for pelagic bacteria were also obtained from in situ growth experiments in dialysis cultures (Cole et al., 2006). Besides, isotope ratios of algae and bacteria were estimated through SIA of taxon-specific biomarkers, fatty acids of polar lipids (PLFA) as follows (Van den Meersche et al., 2009). Relative concentrations as weights of branched PLFA, specific for bacteria, and polyunsaturated PLFA, specific for microalgae and their weighted average $\delta^{13} \mathrm{C}$ were measured. The isotopic composition of the total algal or bacterial pool was estimated by weighting the $\delta^{13} \mathrm{C}$ values of the taxon-specific fatty acids with their respective concentrations.

Periphytic (epilithic) microalgae were scraped from the substrate using a brush, washed into a small volume of water and filtered through precombusted glass fiber filters (Mulholland et al., 2000), like seston.
In studies of planktonic and benthic invertebrates, samples are usually prepared from whole organisms, because the organisms are simply too small for a specific tissue to be isolated (Fry, 1988; Lancaster and Waldron, 2001). In some studies of comparatively large benthic mussels Anodonta, when different tissues were separated, no significant difference was found between foot and mantle tissue $\delta^{13} \mathrm{C}$ values (Perga et al., 2006). In most cases organisms were held in laboratory in filtered lake or river water for 2 - $24 \mathrm{~h}$ (usually overnight) ore more to allow gut clearance prior to further processing (Beaudoin et al., 1999; Mulholland et al., 2000; O'Reilly et al., 2002; Matthews and Mazumder, 2003; Vuorio et al., 2007; Syväranta et al., 2008; Persaud et al., 2009). Instead of the holding in filtered water, guts and their contents may be removed from frozen and thawed insect larvae (Lancaster et al., 2005). Mateo et al. (2008) studied the effect of the removal of the gut content on the stable isotope contents in marine invertebrates and found that the overall effect was insignificant: $0.3 \%$ increase both of the $\delta^{13} \mathrm{C}$ and $\delta^{15} \mathrm{~N}$ values. Nevertheless, by-class analysis yielded a signifcant effect for Gastropoda $\left(\delta^{13} \mathrm{C}\right.$ decrease of $5.4 \%$ ) and Maxillopoda $\left(\delta^{13} \mathrm{C}\right.$ increase of $2.7 \%$ and $\delta^{15} \mathrm{~N}$ increase of $3.2 \%$ ). Therefore, the authors concluded that the gut content evacuation should be ensured whenever possible (Mateo et al., 2008). In contrast, other authors suggested that allowing zooplankton to evacuate their guts before analysis had little effect on the stable isotope composition of zooplankton (Smyntek et al., 2007).

After the gut clearance zooplankton usually are collected on $0.45-\mu \mathrm{m}$ glass-fiber filters (e.g., O'Reilly et al., 2002), and individuals of zoobenthos are picked out by forceps (e.g., Grey et al., 2004). Individuals are combined to form a composite sample, large enough for stable isotope analysis: 20-200 individuals of zooplankton and about 10 individuals for zoobenthos, i.e. a 
minimum of $\sim 0.5 \mathrm{mg}$ dry mass (e.g., Lancaster et al., 2005; Persaud et al., 2009).

Small fish samples (e.g., young of year) usually are entire fish (Cole et al., 2002). For large fish filets of white muscle tissue are dissected (Fry, 1988; Cole et al., 2002). Bodies of individuals too small to be filleted are analyzed after removal of head, tail and viscera (Keough et al., 1996; O'Reilly et al., 2002).

The samples of POM, invertebrates and fish are oven dried $\left(50-60^{\circ} \mathrm{C}\right.$ for $\left.24-72 \mathrm{~h}\right)$ and homogenized, e.g., ground with a mortar and pestle (Keough et al., 1996; Beaudoin et al., 1999; O'Reilly et al., 2002; Grey et al., 2004; Lancaster et al., 2005; Persaud et al., 2009).

In some studies (e.g., Kanaya et al., 2009; Persaud et al., 2009) samples before drying were acidified with dilute $\mathrm{HCl}, 1 \mathrm{M}$ for benthic invertebrates (Beaudoin et al., 1999) or 0.01 $\mathrm{M}$ for zooplankton (O'Reilly et al., 2002), to remove the possible traces of carbonates from the exoskeletons and then rinsed with distilled or deionized water. Nevertheless, some researchers did not use the acid treatment (e.g., Keough et al., 1996). Mateo et al. (2008) analyzed literature data on about 1500 entries of acid washing prior to analysis of samples of marine invertebrates. They concluded that acidifying whole individuals would probably introduce more error due to the removal of dietary $\mathrm{C}$ fractions from the soft tissues than that due to leaving small amounts of carbonate in the sample. Distilled water rinsing of acidified samples also showed a weak overall effect (Mateo et al., 2008).

Because lipids may be depleted in ${ }^{13} \mathrm{C}$ (see below) and thereby affect ecological interpretations, some researchers advocate routine soft lipid extraction prior to SIA by washing in non-polar solvents like hexane or 1:1 methanol:chloroform (Beaudoin et al., 1999; Mateo et al., 2008). For instance, after removing the lipid isotopic influence, the average $\delta^{13} \mathrm{C}$ enrichment was $+1.4 \%$ for Cyclops, $+1.5 \%$ for Daphnia and $+0.8 \%$ for Diaptomus (Ventura and Catalan, 2008). Nevertheless, other authors are more cautious, because the lipid extraction can increase variance and reduce statistical power (Lancaster and Waldron, 2001), and also can cause significant increases in the $\delta^{15} \mathrm{~N}$ values of whole zooplankton and fish tissue samples relative to nonextracted replicates (Smyntek et al., 2007).

Since the stable isotope analyses have been widely applied in aquatic ecology only in last two decades, retrospective investigations of archived material, i.e., fixed samples, for describing past effects of anthropogenic ecosystem alterations or natural shifts in ecosystems are very desirable. Ventura and Jeppesen (2009) demonstrated using their original and literature data, that fixation effect of formalin, ethanol or lugol, if any, occurs within few hours and then the isotope values are subsequently constant. In any case, the isotopic composition of fixed samples correlated well with those of the non-fixed samples and therefore can be used in retrospective stable isotope studies (Ventura and Jeppesen, 2009). Canuel et al. (1995) also noted that the relative trends in fixed samples should be unaffected and thereby they can be used for inter-comparison in some ecological analyses.

\section{The basis of using isotopic measurements to study trophic structure}

The basis of using isotopic measurements to study trophic structure lies in documenting regular and consistent differences of the isotopic values, $\delta^{13} \mathrm{C}$ and $\delta^{15} \mathrm{~N}$, between terrestrial and aquatic organisms on the one hand and between organisms of different trophic levels on the other hand. The differences between terrestrial and aquatic organisms (organic matter) are caused by peculiarities of sources of inorganic carbon and nitrogen. The average $\delta^{13} \mathrm{C}$ for atmospheric $\mathrm{CO}_{2}$ 
is -7 - $-8 \%$ (Cole et al., 2002; Gu et al., 2006). Isotopic values of DIC can have comparatively very low values, $-28.2 \%$ in East Long Lake (Cole et al., 2002), but also up to $4.3 \%$ in Lake Wauberg (Gu et al., 2006). Nevertheless, in general the dissolved inorganic carbon pool exploited by freshwater photosynthetic organisms is more depleted in ${ }^{13} \mathrm{C}$ than atmospheric $\mathrm{CO}_{2}$, which is the carbon source of terrestrial plants (Lancaster and Waldron, 2001). Thus, allochthonous material in freshwater systems, originated from terrestrial vegetation, typically have the carbon signals that are higher than for algae (e.g., Füreder et al., 2003; Lau et al., 2009).

The initial peculiarities of isotopic composition of the inorganic sources are consecutively modified by organisms of increasing trophic levels. The general rule is that the light isotopic molecule in the molecular weight base has a larger rate constant in biochemical reactions than that of the heavier isotopic molecule (Wada, 2009). Therefore, during $\mathrm{C}$ uptake, photosynthetic organisms preferentially assimilate light isotopes, ${ }^{12} \mathrm{C}$, and discriminate against heavy isotopes, ${ }^{13} \mathrm{C}$ (e.g., Finlay et al., 1999, Finlay, 2001; Gu et al., 2006). Also ${ }^{12} \mathrm{C}$ is preferentially respired during respiration (Pond et al., 2006). This enzymatic discrimination results in metabolic fractionation of the isotopes in living organisms compare to that of their carbon source. Thereby, plants have lower isotope values, than their sources of inorganic carbon. Terrestrial C3 plants, which are dominant vegetation, have $\delta^{13} \mathrm{C}$ values about $-28 \%$, and particulate terrestrial detritus in majority of studied temperate aquatic ecosystems have well-constrained mean $\delta^{13} \mathrm{C}$ value of $-28 \%$, ranging between $-34 \%$ and -22 \%o (Finlay, 2001, 2004; Cole et al., 2002). C4 and CAM (Crassulacean acid metabolism) plants, mainly tropical and salt grasses, which are known to efficiently accumulate and store
$\mathrm{CO}_{2}$ due to enzymatic reactions via malate or oxaloacetate, have $\delta^{13} \mathrm{C}$ about $-13 \%$ (Peterson and Fry, 1987).

Major biochemical components (lipids, proteins, carbohydrates) differ in $\delta^{13} \mathrm{C}$ signatures. In particular, lipids have a lower $\delta^{13} \mathrm{C}$ value than the other major components (protein and carbohydrate fractions) and the total organism (e.g., DeNiro and Epstein, 1977; Vander Zanden and Rasmussen, 2001). It was found experimentally by growing E.coli on different carbon sources, that most of the ${ }^{13} \mathrm{C}$ depletion lipids occurred during their synthesis, namely during the oxidation of pyruvate to acetyl CoA. Kinetic isotope effects during the pyruvate dehydrogenase reaction account for the ${ }^{13} \mathrm{C}$ depletion of the lipid fraction observed in organisms as they exist in nature (DeNiro and Epstein, 1977). Thus, whole-body isotope values of species with high lipid loads may be more depleted in ${ }^{13} \mathrm{C}$ than species with low lipid loads (Lancaster and Waldron, 2001).

The fractionation also occurred during metabolism of compounds of nitrogen. Amino acids derived from protein breakdown are deaminated to keto acids, a portion of which are reaminated and reincorporated into body tissue. Each transamination results in nitrogen isotope discrimination, and isotopically light nitrogen ${ }^{14} \mathrm{~N}$ is primarily excreted both as $\mathrm{NH}_{4}^{+}$and urea, while the remaining body material is isotopically enriched in ${ }^{15} \mathrm{~N}$ (Peterson and Fry, 1987; Fantle et al., 1999; Ventura and Catalan, 2008). Microbial nitrogen transformations (nitrification and denitrification) considerably modify the $\delta^{15} \mathrm{~N}$ values of both $\mathrm{NH}_{4}{ }^{+}$and $\mathrm{NO}_{3}{ }^{-}$as both processes preferentially take up ${ }^{14} \mathrm{~N}$ from the substrate pool, and phytoplankton can effectively discriminate between ${ }^{15} \mathrm{~N} /{ }^{14} \mathrm{~N}$ (Syväranta et al., 2008).

All the above peculiarities of the isotopic signatures give a good opportunity to trace flows of organic matter in trophic webs and to measure a trophic position of organism. 


\section{Trophic enrichment}

The trophic fractionation, i.e., difference between $\delta^{13} \mathrm{C}$ or $\delta^{15} \mathrm{~N}$ of consumer's tissues and those of its diet is generally referred to as enrichment, denoted by the symbol $\Delta$ (Fry, 1988; Vanderklift and Ponsard, 2003). In general, the stable carbon isotope enrichment of consumers relative to their food, $\Delta \delta^{13} \mathrm{C}$, is lower $\sim 1 \%$, while $\Delta \delta^{15} \mathrm{~N}$ is significantly higher, $\sim 3 \%$, because organisms preferentially excrete the lighter nitrogen isotope (Fry, 1988; Peterson et al., 1993; Beaudoin et al., 1999; Lancaster and Waldron, 2001; Vander Zanden and Rasmussen, 2001; Syväranta et al., 2008; Ventura and Catalan, 2008). Thus, the carbon isotopic ratios of organisms $\left(\delta^{13} \mathrm{C}\right)$ due to little enrichment generally reflect the isotopic composition of their diet, and thereby provide information on the original source of carbon to the food web. In contrast, the nitrogen isotope ratios $\left(\delta^{15} \mathrm{~N}\right)$ become significantly enriched at successive trophic levels, thereby allowing estimates of consumer trophic position (Beaudoin et al., 1999; Vander Zanden \& Rasmussen, 2001).

Prior to use of the stable isotope technique in ecology 'trophic level' was mainly theoretical notion rather than a measurable value. The 'traditional' approach of grouping animals into discrete trophic levels and deriving food chain length by a simple count may underestimate the degree of complexity and prevalence of omnivory in ecosystems (Lau et al., 2009). The trophic enrichment, $\Delta \delta^{15} \mathrm{~N}$, provides a measure of an organism's trophic position based on its long-term assimilated diet (Beaudoin et al., 1999). Trophic position (TP) is defined as a noninteger value that represents the energyweighted number of trophic energy transfers leading to a consumer:

$$
\mathrm{TP}_{\mathrm{x}}=\left(\delta^{15} \mathrm{~N}_{\mathrm{x}}-\delta^{15} \mathrm{~N}_{\text {base }}\right) / \Delta \delta^{15} \mathrm{~N}+\mathrm{TP}_{\text {base }}
$$

where $\delta^{15} \mathrm{~N}_{\mathrm{x}}$ is the isotope ratio of the taxon in question, $\Delta \delta^{15} \mathrm{~N}$ is the trophic enrichment (fractionation) constant, $\delta^{15} \mathrm{~N}_{\text {base }}$ and $\mathrm{TP}_{\text {base }}$ are the average $\delta^{15} \mathrm{~N}$ and trophic position of the baseline, respectively (Vander Zanden and Rasmussen, 2001; Nilsen et al., 2008). The calculation of TP requires a priori estimats of a trophic enrichment constant value. Typically, the constant $\Delta \delta^{15} \mathrm{~N}=$ 3.4 \%o (Vander Zanden and Rasmussen, 2001; Barnard et al., 2006; Nilsen et al., 2008; Lau et al., 2009), although some other values may be used, e.g., for whole fish $\Delta \delta^{15} \mathrm{~N}=2.9 \%$, for fish muscle $\Delta \delta^{15} \mathrm{~N}=3.2 \%$ (Nilsen et al., 2008).

Producers have highly variable isotopic composition (see below) and they are not used as the baseline for calculations of TP. Consumers through their diets integrate and average out isotopic variations that occur at the lowest phytoplankton trophic level (Fry, 1988), and a taxon of consumers with known trophic position, usually herbivore or detritivore, is used as the baseline. Thus, $\mathrm{TP}_{\text {base }}=2$. For instance, in Sorfjord (Norway) ecosystem study Calanus finmarchicus was selected as the baseline consumer with $\mathrm{TP}_{\text {base }}=2$ based on the assumption that it is a phytoplankton feeder (Nilsen et al., 2008). Longlived primary consumers, such as filter feeding mussels, also have been promoted as suitable baseline indicators which could integrate the temporal variation of $\delta^{15} \mathrm{~N}$ values (Syväranta et al., 2008). In tropical streams for each shading condition in each season, the taxonomic group with the lowest $\delta^{15} \mathrm{~N}$ was selected as the baseline for estimating the TPs of other taxa (Lau et al., 2009).

Although $\Delta \delta^{15} \mathrm{~N}$ is used in the TP calculation as the constant, its value is variable. Vander Zanden and Rasmussen (2001) reviewed $35 \Delta \delta^{15} \mathrm{~N}$ estimates from 22 studies and 20 species and found out, that $\Delta \delta^{15} \mathrm{~N}$ values ranged from $-0.7 \%$ to $9.2 \%$, with an overall mean ( $\pm 1 \mathrm{SD})$ of $2.92 \pm$ $1.78 \%$. Field $\Delta \delta^{15} \mathrm{~N}$ estimates were significantly 
higher than estimates from the laboratory (3.41 $\pm 0.20 \%$ vs. $2.69 \pm 2.11 \%$ ), and estimates for carnivores were significantly higher than for herbivores $(3.23 \pm 0.41 \%$ vs. $2.52 \pm 2.5 \%$ ). Invertebrates were significantly more variable than fish, laboratory estimates were more variable than field estimates, and herbivores were more variable than carnivores (Vander Zanden and Rasmussen, 2001). Nevertheless, enrichment in $\delta^{15} \mathrm{~N}$ from prey to predator $\left(\Delta \delta^{15} \mathrm{~N}\right)$ was relatively consistent across lakes, with an average of $3.49 \pm$ 0.23 \% (Vander Zanden and Rasmussen, 2001). In the following work $\Delta \delta^{15} \mathrm{~N}$ values as low as $1.5 \%$ was reported (O'Reilly et al., 2002).

In contrast, $\Delta \delta^{13} \mathrm{C}$ values ranged only from $-2.1 \%$ to $2.8 \%$, with an overall mean of $0.47 \%$ o $\pm 1.23 \%$ (Vander Zanden and Rasmussen, 2001). Thus, as reported above, $\delta^{13} \mathrm{C}$ signatures are used primarily for tracing of flows of organic matter in trophic webs. For this aim it is important to know peculiarities of the isotopic composition of diverse taxa and ecological groups (life forms) in different habitats.

\section{Isotope ratio differences between taxa and life forms}

Among three groups of aquatic producers, macrophytes had comparatively high $\delta^{13} \mathrm{C}$ values, which ranged in the reviewed literature from $-29.2 \%$ (reed Phragmatis australis) to $-10.1 \%$ (charophytes Najas marina) (Piola et al., 2008). Carbon isotope signatures of phytoplankton ranged from $-32.6 \%$ (Keough et al., 1996) to $-15.8 \%$ (Gu et al., 2006). The lowest $\delta^{13} \mathrm{C}$ value, $-44 \%$, were reported for phytobenthos, namely for epilithic microalgae (Finlay, 2004), although the upper value for this group was $-12.9 \%$ (Piola et al., 2008). The above general tendency was explicit also in specific habitats. For instance, wetland phytoplankton were depleted in ${ }^{13} \mathrm{C}$ relative to aquatic plants (Keough et al., 1996), and benthic algae $\left(\delta^{13} \mathrm{C}=-17.6 \pm 0.3 \%\right)$ in a salt marsh were depleted compare to macrophytes, smooth cordgrass Spartina alterniflora $\left(\delta^{13} \mathrm{C}=-13.9 \pm 0.8 \%\right.$ ) (Fantle et al., 1999).

In the reviewed literature nitrogen isotope ratios $\left(\delta^{15} \mathrm{~N}\right)$ of macrophytes varied from $-11.2 \%$ for charophytes Najas marina (Piola et al., 2008) to $9.8 \%$ for emergent herbaceous species (Keough et al., 1996), while those of phytoplankton ranged from $-0.6 \%$ (Keough et al., 1996) to $7.3 \%$ (Fantle et al., 1999), and those of benthic algae varied from $1.2 \%$ (Lancaster et al., 2005) to $5.8 \%$ (Fantle et al., 1999). Thus, in contrast to the carbon isotope ratio, $\delta^{15} \mathrm{~N}$ values of the three groups of aquatic producers did not have a tendency to differ.

Within the above groups of producers some taxon-specific and life form-specific differences in $\delta^{13} \mathrm{C}$ value were reported. For instance, in the tidal river and estuary of the Scheldt green algae had much more depleted ( 5-10\%) isotope values than diatoms. This can be explained by bicarbonate $\left(\mathrm{HCO}_{3}{ }^{-}\right)$uptake by diatoms, because bicarbonate has a higher $\delta^{13} \mathrm{C}$ value than $\mathrm{CO}_{2}$, and green algae relying only on $\mathrm{CO}_{2}$ (Van den Meersche et al., 2009). In California streams macroalgae showed taxon-specific temporal patterns in $\delta^{13} \mathrm{C}$. Lemanea $\delta^{13} \mathrm{C}$ values were highly ${ }^{13} \mathrm{C}$-depleted relative to all taxa except Cladophora in the spring, where Nostoc $\delta^{13} \mathrm{C}$ values were highly ${ }^{13} \mathrm{C}$-enriched relative to all taxa (Finlay, 2004). Concerning life forms of macrophytes, Keough et al. (1996) found out in wetland ecosystem that submersed plant species were enriched in ${ }^{13} \mathrm{C}$ relative to emergent taxa (the range of $\delta^{13} \mathrm{C}$ values from $-22.5 \%$ to $-18.6 \%$ vs. from $-29.1 \%$ to $-25.9 \%$, respectively), and floating-leaved species exhibited values intermediate between these two groups (from $-24.8 \%$ to $-23.6 \%$ ). Concerning the nitrogen isotope ratio, diatoms can have relatively high $\delta^{15} \mathrm{~N}$ values compared with other phytoplankton taxa (Gentsch et al., 2009). 
Zooplankton $\delta^{13} \mathrm{C}$ values in the reviewed literature varied from $-38.9 \%$ (Karlsson, 2007) to $-17.4 \%$ (Fantle et al., 1999). Gentsch et al. (2009) summarized data on the carbon isotope ratios for marine calanoid copepods from the northern hemisphere and reported range from $-24.9 \%$ to $-11.8 \%$. In coastal lakes in British Columbia there were found no significant amonglake differences in zooplankton $\delta^{13} \mathrm{C}$ but large and significant within-lake differences among zooplankton taxa (Matthews and Mazumder, 2003). In most part of the lakes, studied by the above authors, the $\delta^{13} \mathrm{C}$ of calanoid copepods was lower than Daphnia or Holopedium, resulting in a mean difference $(\sim 2.0 \%$ o) that was significantly greater than zero. One of likely explanations for why calanoid copepods were depleted in ${ }^{13} \mathrm{C}$ relative to Daphnia or Holopedium is that lipids are isotopically lighter than other body constituents, and since copepods can store more lipids than other zooplankton taxa they may generally have lighter $\delta^{13} \mathrm{C}$ signatures (Matthews and Mazumder, 2003). A substantial portion of the frequently observed differences in $\delta^{13} \mathrm{C}$ values between coexisting cladocerans and copepods may be explained by differences in fatty acid content (Smyntek et al., 2007). In contrast, no significant differences of $\delta^{13} \mathrm{C}$ were found between Copepoda and Cladocera, between adults and juveniles in the tidal river and estuary of the Scheldt (Van den Meersche et al., 2009). Ventura and Catalan (2008) reported gender differences in the $\delta^{13} \mathrm{C}$ values of Cyclops, females being slightly more depleted ( $-28.6 \%$ compare to $-27.1 \%$ of males).

Zoobenthos $\delta^{13} \mathrm{C}$ signatures ranged from $-65.2 \%$ for Chironomus plumosus (Grey et al., 2004) to $-11.7 \%$ (Borderelle et al., 2008) and at the minimum were significantly depleted compare to those of zooplankton. Ch. plumosus in six lakes in the U.K. and Germany was consistently depleted in ${ }^{13} \mathrm{C}$ relative to Chironomus anthracinus (Grey et al., 2004). For marine macroinvertebrates (generalization of about 1500 entries) the average $\delta^{13} \mathrm{C}$ value for all the considered was $-18.7 \%$ (Mateo et al., 2008). According to the review of above authors, the lowest average, $-22.4 \%$, were reported for Maxillopoda and the highest average, $-12.7 \%$, was found for chitons (Polyplacophora). There was no taxon effect (insect larvae and mollusks) on the $\delta^{13} \mathrm{C}$ values in studied 11 French lakes, except Dreissena showed a significantly lower $\delta^{13} \mathrm{C}$ value than the other taxa in one lake (Borderelle et al., 2008).

Literature data on the carbon isotope ratio for fish varied from to $-34.4 \%$ for Esox lucius (Beaudoin et al., 1999) to $-15.8 \%$ for marine skates Raja (Fry, 1988) and thereby completely overlapped with those for zooplankton and partly with zoobenthos. No explicit data on taxonspecific patterns of fish $\delta^{13} \mathrm{C}$ were found in the reviewed literature.

\section{Isotope ratio differences between habitats}

The stable isotope composition of marine food webs tends to be more enriched for ${ }^{13} \mathrm{C}$ compared with freshwater biomes, especially concerning minimum values (Fig. 1). Ranges of variations of $\delta^{13} \mathrm{C}$ in freshwater organisms seemed to be significantly wider, than those of marine organisms (Fig. 1).

The above general tendency of an increase of $\delta^{13} \mathrm{C}$ from fresh to marine waters (Hobson, 1999) may be explicit in specific locations. For instance, the $\delta^{13} \mathrm{C}$ values of POM increased consistently along the freshwater-seawater continuum and were significantly correlated with salinity (Canuel et al., 1995). Large differences in $\delta^{13} \mathrm{C}$ (about $-27 \%$ and $-19 \%$, respectively) were observed St. Lawrence River estuary between the freshwater and estuarine algae (Barnard et al., 2006). The isotope signatures of POM gradually increased downstream the tidal river and estuary of the Scheldt from values of $-32 \%$ to $-26 \%$ 


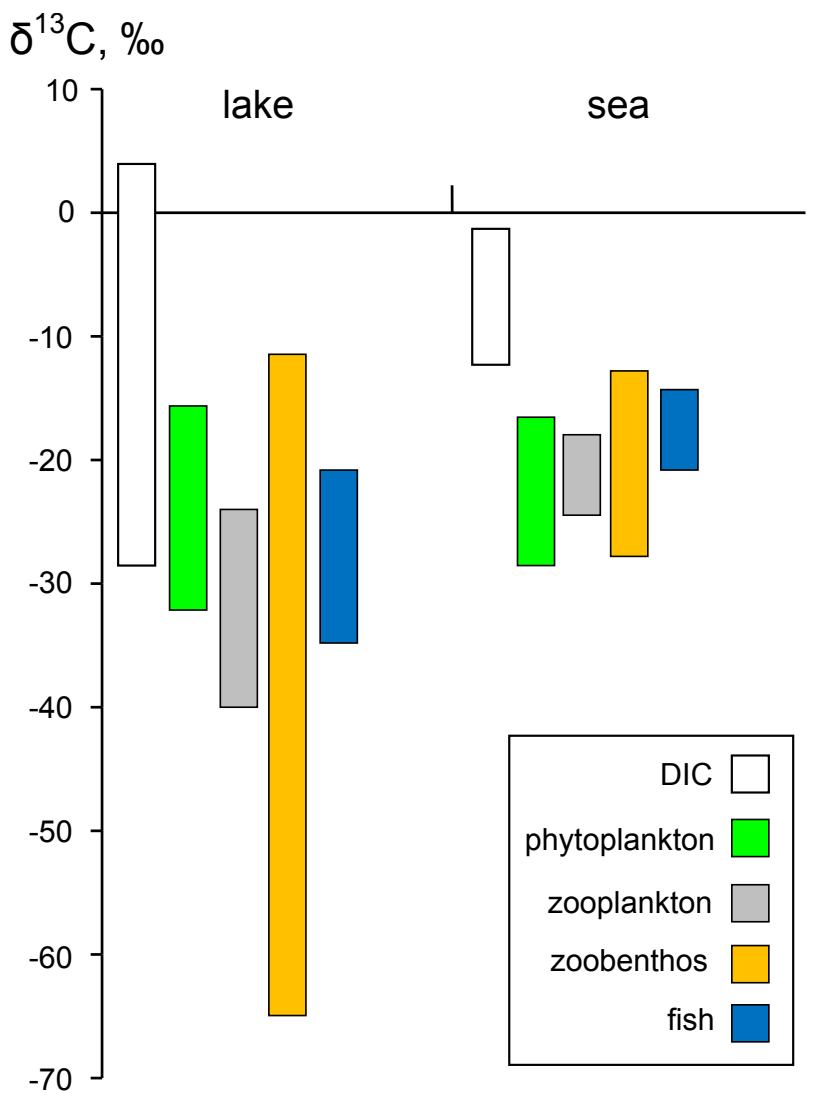

Fig. 1. Ranges of $\delta^{13} \mathrm{C}$ values of dissolved inorganic carbon (DIC) and aquatic organisms in lakes and seas (Fry, 1988; Canuel et al., 1995; Beaudoin et al., 1999; Fantle et al., 1999; Finlay, 2001; O'Reilly et al., 2002; Grey et al., 2004; Gu et al., 2006; Karlsson, 2007; Borderelle et al., 2008; Mateo et al., 2008; Nilsen et al., 2008; Kanaya et al., 2009).

(Van den Meersche et al., 2009). A number of authors used $\delta^{13} \mathrm{C}$ analyses to infer relative use of marine versus freshwater foraging sites by some water birds (Hobson, 1999).

Within marine and freshwater aquatic systems, $\delta^{13} \mathrm{C}$ gradients in food webs may be related to inshore or benthically linked food webs versus offshore or pelagic food webs. Pelagic primary producers show $\delta^{13} \mathrm{C}$ values near $-31 \%$, benthic primary producers show higher $\delta^{13} \mathrm{C}$ values near $-17 \%$ and terrestrial primary producer $\delta^{13} \mathrm{C}$ values are near $-27 \%$ (Borderelle et al., 2008). In general, inshore, benthically linked food webs are believed to be more enriched in ${ }^{13} \mathrm{C}$ compared with offshore, pelagic food webs (Hobson, 1999). Particulate matter in coastal waters often has higher $\delta^{13} \mathrm{C}$ signatures than in oceanic waters due to the inflow of allochthonous material such as land-derived matter while in shallow waters resuspension of benthic material such as detritus and macroalgal fragments increases the $\delta^{13} \mathrm{C}$ values (Gentsch et al., 2009).

Nevertheless, the above tendency was not confirmed in some freshwater system. In contrast, plankton, collected from Lake Superior, had $\delta^{13} \mathrm{C}$ between -29 and $-23 \%$, while organisms from an adjacent wetland exhibited more depleted $\delta^{13} \mathrm{C}$ values between -32 and $-27 \%$, and this difference roughly corresponded to the difference in DIC in the two habitats (Keough et al., 1996). The cited authors supposed that decomposition and respiration processes in the streams and wetland would be expected to contribute inorganic carbon that is depleted in ${ }^{13} \mathrm{C}$, while airborne $\mathrm{CO}_{2}$, 
incorporated through turbulence and diffusion, likely dominates the inorganic $\mathrm{C}$ of surface waters of the lake.

Stable carbon isotope ratio values also depend on depth. Respired carbon from heterotrophic metabolism is isotopically lighter than consumed carbon source and high epilimnetic respiration relative to production can result in a depletion of the $\delta^{13} \mathrm{C}$ of dissolved inorganic carbon (Matthews and Mazumder, 2003). Thus, deep-water DIC is depleted relative to surface DIC (O'Reilly et al., 2002), and also $\delta^{13} \mathrm{C}$ signature of metalimnetic POM in some lakes is depleted by $>1 \%$ relative to epilimnetic POM (Matthews and Mazumder, 2003). Moreover, in deep lakes isotopically light biogenic methane is produced in anoxic sediments, and its incorporation in trophic webs caused extremely depleted $\delta^{13} \mathrm{C}$ values of chironomid larvae, as low as $-65.2 \%$ (Grey et al., 2004).

In lotic ecosystems $\delta^{13} \mathrm{C}$ DIC of cold spring streams (headwaters) were strongly depleted relative to river water (Finlay, 2001). Both epilithic algae and herbivore $\delta^{13} \mathrm{C}$ were enriched by an average of 5-8\% in pools compared to riffles in productive rivers (Finlay et al., 1999). Periphyton was more $\delta^{13} \mathrm{C}$-enriched in unshaded than shaded streams (Lau et al., 2009), probably because in unshaded areas a higher photosynthesis resulted in a limit of $\mathrm{CO}_{2}$ and thus in a lower isotope fractionation.

The above differences in the isotope ratio values were related to different ecosystems, primarily inhabited by different species. Nevertheless, the same species in different habitats also may differ in their isotope signatures. For instance, the carbon isotope compositions of blue crab populations of the Delaware Bay $\left(\delta^{13} \mathrm{C}=-16.5 \%\right.$ ) were significantly different from crabs in the adjacent Great Marsh $\left(\delta^{13} \mathrm{C}=-15.1 \%\right.$ ) (Fantle et al., 1999). Freshwater shrimp Paratya australiensis sampled from benthic cyanobacterial
(Aphanothece) accumulations assimilated the cyanobacteria and had $\delta^{13} \mathrm{C}$ values $2.2 \%$ higher than that of shrimp from control habitats (Piola et al., 2008). In Schohsee Chironomus anthracinus larvae from $15 \mathrm{~m}\left(\delta^{13} \mathrm{C}-32.7 \%\right.$, $\delta^{15} \mathrm{~N} 5.0 \%$ were significantly depleted in both ${ }^{13} \mathrm{C}$ and ${ }^{15} \mathrm{~N}$ relative to those from $10 \mathrm{~m}\left(\delta^{13} \mathrm{C}-27.9 \%\right.$, $\left.\delta^{15} \mathrm{~N} 7.0 \%\right)$.

As to $\delta^{15} \mathrm{~N}$ signatures, they also often can differ in diverse habitats apart from the trophic fractionation, described in the previous capter. For instance, deep-water nitrogen is likely enriched in ${ }^{15} \mathrm{~N}$, because denitrification occurs in the suboxic section of the water column and the lighter isotope is selectively removed and the remaining nitrate becomes increasingly enriched in ${ }^{15} \mathrm{~N}$ (O'Reilly et al., 2002). According to literature generalization of the above authors, denitrification has fractionations in the range of 10 to $30 \%$, which would lead to an enriched nitrate pool in the suboxic metalimnion.

$\mathrm{Gu}$ (2009) in his literature review concluded, that lakes of different geographical locations and morphometries may be different in the sources and isotopic composition of particulate and dissolved matter that can profoundly infuence the $\delta^{15} \mathrm{~N}$ of POM. The seasonal mean $\delta^{15} \mathrm{~N}_{\text {POM }}$, reported in literature for 36 lakes with data from multiple sampling events, varied from -0.5 to $13.3 \%$. The $\delta^{15} \mathrm{~N}_{\text {Pom }}$ in small lakes ( $\leq$ $1 \mathrm{~km}^{2}$ ) were 3.1 and $3.7 \%$ more depleted than in the mid-size and large lakes. The seasonal mean $\delta^{15} \mathrm{~N}_{\text {POM }}$ increased from $4.6 \%$ in the oligotrophic lakes to $7.3 \%$ in eutrophic lakes. Seasonal $\delta^{15} \mathrm{~N}_{\text {POM }}$ amplitude ranged from 1.4 to $25.0 \%$ with a mean of $7.7 \%$. This withinlake variability is larger than the among-lake variability. The cited author also emphasized, that nitrogen-fixing cyanobacteria do not have significant fractionation against ${ }^{15} \mathrm{~N}$ during the uptake of atmospheric $\mathrm{N}_{2}$, therefore, the $\delta^{15} \mathrm{~N}$ of POM dominated by $\mathrm{N}_{2}$-fxing cyanobacteria is close to $0 \%$ (Gu, 2009). 


\section{Environmental factors affecting values of isotope ratios}

The above differences in the isotopic ratios between organisms and habitats are evidently caused by mechanisms of fractionation, partly mentioned above. Here we will try to summarize the environmental factors, which triggered the mechanisms and caused peculiarities of the isotope signatures in diverse ecosystems.

Primary productivity is a fundamental factor affecting aqueous inorganic $\mathrm{C}$ dynamics and isotope fractionation of organic matter (Canuel et al., 1995; Finlay et al., 1999; Finlay, 2001; Pel et al., 2003; Gu et al., 2006; Borderelle et al., 2008). There is an inverse relationship between the growth rate of algae and the extent of discrimination against ${ }^{13} \mathrm{CO}_{2}$ in photosynthesis (Pel et al., 2003). Limited $\mathrm{CO}_{2}$ supply relative to photosynthetic demand (i.e., carbon limitation) increases algal $\delta^{13} \mathrm{C}$ through reduced discrimination against ${ }^{13} \mathrm{C}$ when the entire pool of available $\mathrm{CO}_{2}$ is used (Canuel et al., 1995; Finlay, 2001). Effects of carbon limitation result in enriched algal $\delta^{13} \mathrm{C}$ (Finlay et al., 1999). For instance, in the San Francisco Bay estuary $\delta^{13} \mathrm{C}$ of the seston (POM) was generally in the range of -24 to $-27 \%$ except during spring phytoplankton (diatom) bloom, when the seston $\delta^{13} \mathrm{C}$ values were significantly enriched, from -17 to $-19 \%$ (Canuel et al., 1995). In general, the high $\delta^{13} \mathrm{C}$ of seston was accompanied by high water temperature, high phytoplankton biovolume, high $\mathrm{pH}$, and low DIC concentration. In contrast, sestonic $\delta^{15} \mathrm{~N}$ was not correlated with any above ambient variables (Gu et al., 2006).

Stable-carbon-isotope-ratios of benthic algae in lotic ecosystems also depend on $\mathrm{CO}_{2}$ availability determined by current velocity (Finlay, 2001). The maximum carbon isotope fractionation by benthic algae occurred in stream habitats where $\mathrm{CO}_{2}$ supply rate (i.e., current velocity) was highest. Water stagnation could enrich algal $\delta^{13} \mathrm{C}$ through both boundary layer effects and low $\mathrm{CO}_{2}$ concentrations caused by warm water temperatures. In contrast to productive rivers, current velocity did not affect algal $\delta^{13} \mathrm{C}$ in the unproductive tributary streams, suggesting that $\mathrm{CO}_{2}$ availability relative to rates of primary production determines current velocity effects on algal carbon isotope ratios (Finlay et al., 1999).

Unlike algae, which show less isotope fractionation during periods of high growth, consumers, e.g., juvenile crabs, which grew faster on a high-quality diet (zooplankton), did not significantly fractionate dietary carbon and nitrogen, while the juveniles which grew at the slowest rate on a low-quality food (detritus), significantly fractionated carbon and nitrogen isotopes, relative to diet (Fantle et al., 1999). The authors speculated that the rapidly growing crab utilized a substantial amount of nitrogen from the diet in the synthesis of tissue, while a slowly growing crab must catabolize its own proteins for energy. When the proteins are catabolized, light nitrogen is preferentially excreted as $\mathrm{NH}_{3}$, leaving the remaining material enriched in ${ }^{15} \mathrm{~N}$. Thus, a slowly growing crab fractionates nitrogen isotopes to a greater extent than a rapidly growing crab (Fantle et al., 1999). Vanderklift and Ponsard (2003) reported that values of $\Delta \delta^{15} \mathrm{~N}$ significantly increase with increase of $\mathrm{C}: \mathrm{N}$ ratio of the food source. In a laboratory experiment with Chironomus riparius experiment $\mathrm{N}$-fractionation was also inversely related to the $\mathrm{N}$-content of the food (Goedkoop et al., 2006). Enrichment in $\delta^{13} \mathrm{C}$ of Cyclops juveniles increased with their body mass (Ventura and Catalan, 2008).

Phytoplankton may either be enriched or depleted in ${ }^{15} \mathrm{~N}$ depending on which form of nitrogen is used (Gu, 2009). It is commonly assumed that phytoplankton preferentially utilize ammonium $\left(\mathrm{NH}_{4}^{+}\right)$rather than nitrate $\left(\mathrm{NO}_{3}^{-}\right)$, however, preference for nitrogen source by phytoplankton may be taxon-specific and nitrate 
may be a preferred form of nitrogen for larger phytoplankton such as many species of diatoms (Syväranta et al., 2008). These two main forms of nitrogen can have different isotopic ratios. Denitrification has fractionations in the range of 10 to $30 \%$, which would lead to an enriched nitrate pool in the suboxic metalimnion (O'Reilly et al., 2002). In well-oxygenated waters ammonium is oxidized to nitrate in the nitrification process, in which isotopic fractionation produced ${ }^{15} \mathrm{~N}$ depleted $\mathrm{NO}_{3}{ }^{-}$and remaining $\mathrm{NH}_{4}{ }^{+}$pool becomes ${ }^{15} \mathrm{~N}$-enriched. (Syväranta et al., 2008; Gu, 2009). For instance, in Lake Jyväsjärvi dissolved $\mathrm{NH}_{4}{ }^{+} \mathrm{N}$ had average seasonal $\delta^{15} \mathrm{~N}$ values $21.7-$ $29.1 \%$, while $\mathrm{NO}_{3}{ }^{-}-\mathrm{N}$ had the $\delta^{15} \mathrm{~N}$ values $2.9-$ 7.1 \%o (Syväranta et al., 2008). Phytoplankton can effectively discriminate between ${ }^{15} \mathrm{~N} /{ }^{14} \mathrm{~N}$ and fractionation during nitrogen assimilation by phytoplankton can be -4 to $-5 \%$ if nitrogen is in excess (O’Reilly et al., 2002). Fast-growing phytoplankton has less isotopic fractionation during nutrient assimilation and may deplete the nutrient pool, leading to ${ }^{15} \mathrm{~N}$ enrichment, but seasonal increases in primary productivity in lakes dominated by $\mathrm{N}_{2}$-fxing cyanobacteria do not lead to increases in $\delta^{15} \mathrm{~N}$ of POM (Gu, 2009). The above interacting factors may cause significant seasonal changes of $\delta^{15} \mathrm{~N}$ signatures. For instance, in Lake Jyväsjärvi POM and zooplankton $\delta^{15} \mathrm{~N}$ values were lower in spring, increased through summer and peaked in autumn, and the increase in cladocerans was from $6.1 \%$ in May to $23.0 \%$ in October (Syväranta et al., 2008). All the variations in isotopic signatures may confound interpretation of data and, thereby, limit the usage of the stable isotope method for tracing of trophic webs and studying trophic structure.

\section{Limitations of the stable isotope method}

As reported above, the tracing of flows of organic matter in trophic webs is based on the low average enrichment for consumers, $\Delta \delta^{13} \mathrm{C}<1 \%$, while the measuring of trophic position suggests the high and constant average $\Delta \delta^{15} \mathrm{~N} \approx 3.4 \%$. Although many field studies supported these average enrichments (e.g., Fry, 1988; Keough et al., 1996; Vander Zanden and Rasmussen, 2001; Finlay, 2004; Ramirez et al., 2009), there were many exceptions.

Results of the laboratory growth studies indicated that the fractionation of isotopes by consumers were not constant but depended on diet quality (Fantle et al., 1999; Goedkoop et al., 2006). Ventura and Catalan (2008) pointed out that the application of constant average nitrogen fractionation values to establish trophic positions should be applied with caution and usually only when dealing with complex food webs with multiple trophic links and many species. In studies of trophic relationships involving only few species, potential factors of variability in isotopic fractionation should be taken into account, including diet. The lack of a sufficient source of amino acids in a given diet forces a higher nitrogen turnover in consumers and, therefore, a higher isotopic discrimination (Ventura and Catalan, 2008).

Vanderklift and Ponsard (2003) reported significant differences in the nitrogen isotope enrichment between five categories of organisms: 1) ureotelic, excreting mainly urea (mammals, $\Delta \delta^{15} \mathrm{~N} \approx 3.11 \%$ ); 2) uricotelic, excreting mainly uric acid (birds, $\Delta \delta^{15} \mathrm{~N} \approx 2.73 \%$ ); 3 ) ammonotelic, excreting mainly ammonia (aquatic invertebrates and fish, $\Delta \delta^{15} \mathrm{~N} \approx 2.00 \%$ ); 4) guanicotelic, excreting mainly guanine (some spiders, $\Delta \delta^{15} \mathrm{~N}$ $\approx 1.09 \%$ ); 5) organisms excreting mainly amino acids (pea aphid, $\Delta \delta^{15} \mathrm{~N} \approx-0.93 \%$ ).

Lancaster and Waldron (2001) hypothesized that different ${ }^{15} \mathrm{~N}$ baselines likely exist between sources in the same site, e.g., between allochthonous and autochthonous sources. Consequently, carnivores in different food chains within the same food web may have $\delta^{15} \mathrm{~N}$ values 
that reflect different baseline resources more strongly than trophic position. For example, in Scotland streams predatory stonefly Dinocras cephalotes preyed mainly on baetid mayflies that grazed algae and contained more ${ }^{15} \mathrm{~N}$ than predatory caddisfly Rhyacophila dorsalis, which preyed mainly on larval Simuliidae that filter fed on particles of largely terrestrial origin (Lancaster and Waldron, 2001).

There were many reports concerning $\delta^{15} \mathrm{~N}$ trophic fractionation lower than $3.4 \%$. For instance, stonefly Dinocras cephalotes were only $2 \%{ }^{15} \mathrm{~N}$-enriched than the mayfly Baetis rhodani, which is one of its main prey (Lancaster and Waldron, 2001). The $\delta^{15} \mathrm{~N}$ ratios did not show enrichment with increasing trophic level from phyto- to zooplankton in Lake Tanganyika, and adult piscivorous fish Lates stappersi was only $2 \%$ enriched in $\delta^{15} \mathrm{~N}$ relative to its primary prey planktivorous clupeid fish Stolothrissa (O'Reilly et al., 2002). In a laboratory experiment with Chironomus riparius isotopic fractionation of $\delta^{15} \mathrm{~N}$ was on average $1.14 \% 0$ (Akerblom and Goedkoop, 2003). In alpine streams the increase in $\mathrm{N}$ isotopes between consumer and food source was from 1 to $2 \%$ (Füreder et al., 2003). Organisms with carnivorous, herbivorous and mixed diets yielded similar estimates of $\Delta \delta^{15} \mathrm{~N}(2.69 \%, 2.98 \% 0$ and $2.56 \%$ respectively) while organisms consuming detritus yielded significantly lower estimates of $\Delta$ $\delta^{15} \mathrm{~N}(0.53 \%)$ (Vanderklift and Ponsard, 2003). Alternatively, in two lakes different $C$. plumosus individuals exhibited the range of values of $16 \%$ for $\delta^{15} \mathrm{~N}$ equivalent to five trophic levels (Grey et al., 2004).

Another potential source of error in the isotope data interpretation is the time-lag before the $\delta^{15} \mathrm{~N}$ or $\delta^{13} \mathrm{C}$ of consumer's tissues have equilibrated following introduction to a new diet (Vanderklift and Ponsard, 2003). Evidently, time of the equilibration depends on size of organisms and their type of metabolism. For instance, peak ${ }^{13} \mathrm{C}$ was measured in zooplankton at $5 \mathrm{~d}$ after the addition of ${ }^{13} \mathrm{C}$-DIC in the lake (Cole et al., 2002). In contrast, for comparatively large zoobenthic insect larvae and young-of-theyear grayling it took three-six weeks to achieve isotopic equilibration with their food (Peterson et al., 1993). Moreover, other authors found out that in a forest stream only mayfly Stenonema was at isotopic equilibrium with respect to epilithon by the end of the $42-\mathrm{d}{ }^{15} \mathrm{~N}$ tracer addition experiment, but other zoobenthos taxa (Mulholland et al., 2000). Isotopic signatures of adult pike likely reflected diets integrated over the past year or so (Beaudoin et al., 1999). Time of the equilibration also differ between tissues. Hobson (1999) reported that some keratinous tissues like hair, feather, or nail are metabolically inert following synthesis and, so, maintain an isotopic record reflecting the location where the tissue was synthesized. Other tissues are metabolically active and the dietary or source information obtained is a temporal integration ranging from a few days in the case of liver or blood plasma, to several weeks in the case of muscle or whole blood, to the lifetime of the individual in the case of bone collagen (Hobson, 1999). In summary, temporal integration must be considered when comparing organisms whose isotopic compositions average over different time scales (O'Reilly et al., 2002).

On the other hand, it should be noticed that in some cases the temporal integration of isotopic signals at higher trophic levels may play positive role for ecological analyses. Indeed, isotopic signals of primary producers, such as plankton microalgae, are subject to greater variation than other trophic levels because of constantly changing nutrient sources and concentrations (O'Reilly et al., 2002), but consumers through their diets integrate and average out isotopic variations that occur at the lowest phytoplankton trophic level (Fry, 1988). 
One of the limitations of stable isotope analysis may be a lack of standard protocols. Inconsistencies include the type of tissue used for analysis, allowance for zooplankton gut clearance, sample acidification, and the need to extract lipids from zooplankton and fish tissue before stable isotope analysis (Smyntek et al., 2007). The cited authors emphasized, that future studies of fish diet using stable carbon isotope analysis of zooplankton and fish muscle tissue must address differences in lipid content between these two distinct types of samples. They supposed, that this can be achieved by extracting lipids from samples before analysis or by using a mass balance correction model to determine $\delta^{13} \mathrm{C}_{\text {ex }}$ (lipid-extracted $\delta^{13} \mathrm{C}$ values) of zooplankton and fish samples:

$$
\begin{aligned}
& \delta^{13} \mathrm{C}_{\mathrm{ex}}=\delta^{13} \mathrm{C}_{\text {bulk }}+D\left(\left(\mathrm{C}: \mathrm{N}_{\text {bulk }}-\right.\right. \\
& \left.\left.-\mathrm{C}: \mathrm{N}_{\mathrm{ex}}\right) / \mathrm{C}: \mathrm{N}_{\text {bulk }}\right)
\end{aligned}
$$

where $\delta^{13} \mathrm{C}_{\text {bulk }}$ is the isotopic signature of samples without the lipid extraction, $D$ is the average difference between $\delta^{13} \mathrm{C}$ values of protein and lipids in the sample, $\mathrm{C}: \mathrm{N}_{\text {bulk }}$ and $\mathrm{C}: \mathrm{N}_{\mathrm{ex}}$ are atomic $\mathrm{C}: \mathrm{N}$ ratios of the nonextracted and the extracted samples, respectively (Smyntek et al., 2007). The authors reported, that the mass balance correction model provides a simple and efficient method to accurately predict $\delta^{13} \mathrm{C}_{\mathrm{ex}}$ for both copepods and cladocerans using the average values of $D=6.3 \%$ o $\pm 1.3 \%$ and $\mathrm{C}: \mathrm{N}_{\mathrm{ex}}=4.2 \pm 0.4$.

The tracing of carbon flows in food webs may also be confounded. For instance, as reported above, allochthonous material in freshwater systems typically have the carbon signals that are higher than for algae, but additional enrichment of autochthonous organic matter $\delta^{13} \mathrm{C}$ may occur during decomposition due to preferential microbial use of ${ }^{12} \mathrm{C}$ (Finlay, 2001). ${ }^{13} \mathrm{C}$ food web enrichments of up to $6 \%$ have been documented for fungi growing on laboratory and natural substrates (Fry and Ewel, 2003). Moreover, algal and detrital $\delta^{13} \mathrm{C}$ may overlap and thereby complicate food-web analyses (Finlay et al., 1999). For instance, carbon isotope ratios in peat $\left(\delta^{13} \mathrm{C}=-27.1 \%\right)$, in terrestrial plants $(-26.0$ to $-27.3 \%)$, and in epilithon (-27.2\%) collected in a tundra river ecosystem were not sufficiently distinctive to provide a useful tracer of carbon flow (Peterson et al., 1993). Also the strong influence of large fatty acid reserves in some zooplankton, particularly copepods, may often bias $\delta^{13} \mathrm{C}$ values and mask their true relation with phytoplankton food sources (Smyntek et al., 2007). The above limitations of the isotope analysis of bulk carbon can be improved using recently developed compound-specific isotope analysis.

\section{Compound-specific isotope analysis}

Compound-specific isotope analysis (CSIA) has proved useful in a variety of geological and biological studies (Fantle et al., 1999). Commercial instruments for CSIA are nowadays hyphenated mostly to gas chromatography. Although this step has been thoroughly investigated, it implies two major drawbacks: extraneous carbon is introduced in the compound, which causes a shift of the isotopic composition and has to be corrected for in later calculations, and the derivatization reaction is usually characterized by a kinetic isotope fractionation (Schmidt et al., 2004). For fatty acids (FA), which are converted to fatty acid methyl esters (FAME), the necessary corrections can be as follows. The $\delta^{13} \mathrm{C}$ value of the methanol derivatization reagent $\left(\mathrm{CH}_{3} \mathrm{OH}\right)$ is determined by conventional closed tube combustion, and the contribution of derivatized carbon to the biomarker fatty acids is calculated by using the following equation:

$$
\delta^{13} \mathrm{C}_{\mathrm{FA}}=\left(\delta^{13} \mathrm{C}_{\mathrm{FAME}}-(1-x) \delta^{13} \mathrm{C}_{\mathrm{CH} 3 \mathrm{OH}}\right) / x
$$


where $\delta^{13} \mathrm{C}_{\mathrm{FA}}$ is the isotopic composition of the free fatty acids, $\delta^{13} \mathrm{C}_{\mathrm{FAME}}$ is the isotopic composition of the fatty acid methyl ester, $x$ is the fractional carbon contribution of the free fatty acid to the ester and $\delta^{13} \mathrm{C}_{\mathrm{CH} 3 \mathrm{OH}}$ is the isotopic composition of the methanol derivatization reagent (Pond et al., 2006). Thus, stable carbon isotope ratios for individual FA is calculated from FAME data by correcting for the one carbon atom in the methyl group that is added during derivatization (Boschker et al., 2005).

Another way to correct for the contribution from the extra methanol $\mathrm{C}$ and determine any kinetic isotope effects is a transesterification of free fatty acid (FFA) standards with the same reagents (Budge et al., 2008). Prior to transesterification, $\delta^{13} \mathrm{C}$ values for FFA standards are determined using an elemental analyzer attached to IRMS. Then an average correction to apply to FAME data can be calculated as the difference between the $\delta^{13} \mathrm{C}$ values of the corresponding FFA and FAME (Budge et al., 2008).

CSIA revealed many differences in isotopic signatures of individual compounds. For instance, in experimentally cultured crabs and their diets, the essential amino acids, such as valine, leucine, and phenylalanine had the lowest $\delta^{13} \mathrm{C}$ values, whereas non-essential amino acids had the highest ones (Fantle et al., 1999). As the cited authors have remarked, essential amino acids, which cannot be synthesized from a simple glucose skeleton by an organism, are derived directly from the diet and, therefore, undergo few reactions capable of isotope fractionation. Non-essential amino acids enter the tricarboxylic cycle and are, therefore, a subject of many enzyme-catalyzed reactions capable of isotope fractionation (Fantle et al., 1999).

On the basis of CSIA differences between FA isotopic signatures of autotrophs and heterotrophs important for the food webs tracing was found. In laboratory cultures a positive relationship was between the $\delta^{13} \mathrm{C}$ values of biomarker fatty acid, 20:5(n-3), and growth characteristics (population volume) of the marine autotrophic eustigmatophyte Nanochloropsis oculata (Pond et al., 2006). The cited authors suggested that the quantity of autotrophic biomass competing for inorganic carbon resources was the key factor determining $\delta^{13} \mathrm{C}$ values. In contrast, no similar relationships were evident between $\delta^{13} \mathrm{C}$ values of 22:6(n-3) and the population volume of marine heterotrophic dinoflagellate Oxyrrhis marina (Pond et al., 2006). The average $\delta^{13} \mathrm{C}$ value of $16: 4 n-1$ in amphipods and euphausiids collected from the stomachs of cod was almost identical to that of the $\operatorname{cod}(-26.1 \pm 1.1$ vs. $-26.2 \pm 1.1 \%)$ and was not significantly different for 20:5n-3 (-24.0 \pm 1.2 vs. $-24.9 \pm 0.4 \%$ ), suggesting minimal isotopic fractionation during metabolism of these FA (Budge et al., 2008).

There were significant differences in the isotopicratios offattyacids between phytoplankton taxa. Eukaryotic algae (greens and diatoms) and cyanobacteria (Limnothrix and Prochlorothrix) conspicuously differed in their ${ }^{13} \mathrm{C}$ composition of fatty acids by $6-10 \%$ (Pel et al., 2003). Values of $\delta^{13} \mathrm{C}$ for $16: 4 \mathrm{n}-1$ in ice algae (pennate diatoms, $-24.0 \pm 2.4 \%$ ) were significantly higher than those in pelagic phytoplankton (centric diatoms, $-30.7 \pm 0.8 \%$ ), and $\delta^{13} \mathrm{C}$ values of 20:5n-3 in ice algae $(-18.3 \pm 2.0 \%)$ were also higher than in phytoplankton $(-26.9 \pm 0.7 \%$ ) (Budge et al., 2008). Thus, the combination of FA and isotope analyses can be important in clarifying trophic relationships in the local food web that might have been overlooked otherwise (Boschker et al., 2005; Budge et al., 2008; Van den Meersche et al., 2009).

\section{Novel conceptions}

Recent food-web studies with stable isotope analyses have modified our assumptions about the sources of energy to food webs (Keough et al., 
1996). First of all, despite predictions of the river continuum concept that small forested streams should depend mainly on allochthonous energy, patterns in consumer's $\delta^{13} \mathrm{C}$ ratio suggested the importance of autochthonous algal production to stream food webs regardless of shading conditions (Finlay, 2001; Lau etal., 2009). Thus, SIA indicated that algal carbon contributions to river food webs could be substantially underestimated in many cases (Finlay et al., 1999). The isotope study revealed that allochthonous and autochthonous contributions to mesozooplankton diet are of similar magnitude in the food webs of the river and estuary of the Scheldt and mesozooplankton receive very little of their carbon via the bacterial loop (Van den Meersche et al., 2009).

Cole et al. (2002) added the ${ }^{13} \mathrm{C}$ tracer in East Long Lake, where allochthonously derived dissolved organic carbon accounted for more than $90 \%$ of organic $\mathrm{C}$ and respiration (R) exceeded gross primary production (GPP) by large amounts. Nevertheless, zooplankton assimilation was dominated by inputs from phytoplankton, with $59 \%$ coming from living phytoplankton and $31 \%$ from the nonliving POM of autochthonous origin. If the authors had not added the ${ }^{13} \mathrm{C}$ tracer, they could have come to the conclusion that the food web in East Long Lake was supported almost exclusively by allochthonously supplied organic C. The metabolism of allochthonous organic $\mathrm{C}$ by pelagic bacteria was either a direct respiratory sink for the allochthonous $\mathrm{C}$ or supports a microbial loop that does not strongly interact with the food chain supported by phytoplankton production. Thus, the zooplankton and, by extension, the fish that prey on them were components of a food web that was not very dependent on the vast amount of allochthonous $\mathrm{C}$ loading to the lake (Cole et al., 2002). Other authors also reported, that in oligotrophic (net heterotrophic) lakes (i.e., community $\mathrm{R}>\mathrm{GPP}$ ) there are large losses of allochthonous organic carbon in bacterial respiration, and low transfer $(0.7-2.9 \%$ of bacterial metabolized allochthonous $\mathrm{C}$ ) to higher trophic levels, zooplankton (Karlsson, 2007). Nevertheless, in some oligotrophic lake terrestrial particulate organic carbon was important $\mathrm{C}$ source for zooplankton and prey items of terrestrial origin were a significant component for fish (Cole et al., 2006).

In wetlands SIA has indicated that in spite of the large amount of biomass represented as vascular plants, carbon isotope signatures for animals are frequently consistent with an algalbased food web (Keough et al., 1996). Also in a shallow macrophyte-dominated Chany Lake the $\delta^{13} \mathrm{C}$ values of zooplankton and most benthic invertebrates (except for Gammarus lacustris) were similar to those of microalgae (POM and epiphytes), suggesting that the consumers primarily depended on these carbon sources rather than on macrophytes and riparian vegetation (Kanaya et al., 2009). In mangrove forests early studies, based on gut content analyses, indicated a strong food web linkage between decaying mangrove leaves and coastal fisheries, but isotopic studies showed no evidence for assimilation of this material, apparently because the detritus was too refractory. In isotopic studies a dominant food web role for benthic algae rather than for macrophyte detritus has been documented (Fry and Ewel, 2003).

As mentioned above, the common method for study of diet, gut content analyses, often failed to provide true results, because this technique cannot differentiate between materials that are digested and assimilated and those that pass through the alimentary system intact (Lancaster et al., 2005). Thereby, stable isotope analyses, which measured assimilated diet, improved ideas concerning feeding spectra of many species. For instance, the trichopteran Lepidostoma sp., although considered to be primarily a shredder of terrestrial detritus (i.e., leaves or woody debris), 
had $\delta^{13} \mathrm{C}$ that were more similar to pool algae than to terrestrial detritus (Finlay et al., 1999). Northern pike Esox lucius, $>85 \mathrm{~mm}$ length, are often considered to be specialist piscivores, but $\delta^{15} \mathrm{~N}$ signatures of pike ranged over 5-6\%, indicating considerable individual variation that spanned approximately two trophic levels (Beaudoin et al., 1999). Values of $\delta^{15} \mathrm{~N}$ indicated that at least some carnivorous Plecoptera and Trichoptera assimilated algae (Lancaster et al., 2005). Moreover, consumer isotope signatures integrate prey isotope signatures over relatively long periods of time (weeks to years depending on body size and growth rate), offering distinct advantages over gut-content analysis (Beaudoin et al., 1999; Finlay, 2001). The stable isotope analyses also gave strong evidence on selective feeding of organisms, which were commonly regarded simply as detritivores, such as blue crab Callinectes sapidus (Fantle et al., 1999), Chironomus riparius larvae (Akerblom and Goedkoop, 2003) and Unionid mussels Anodonta and Unio (Vuorio et al., 2007). In St. Lawrence River estuary a pronounced $\delta^{13} \mathrm{C}$ offset between zooplankton and seston was an evidence both of strong selectivity by the consumers for prey items that constitute only a minor fraction of the total seston and of weak trophic coupling between consumers and the bulk particulate organic matter (Barnard et al., 2006).

Together with indication of the selective feeding, it is possible to use isotopic ratios to quantitatively determine the proportional contribution of several sources to a diet. Phillips and Gregg (2003) suggested a following approach. In general, the proportional contributions of $n+1$ different sources can be uniquely determined by the use of $n$ different isotope system tracers (e.g., $\delta^{13} \mathrm{C}, \delta^{15} \mathrm{~N}, \delta^{18} \mathrm{O}$ ) with linear mixing models based on mass balance equations. Nevertheless, when the number of potential sources exceeds $n+1$, it prevents finding a unique solution of source proportions (e.g., $\delta^{13} \mathrm{C}$ and $\delta^{15} \mathrm{~N}$ measured, and $>2$ potential food items exist). However, with $n$ isotope systems and $>n+1$ sources, the requirement for mass balance conservation can be use to find multiple combinations of source proportions which are feasible solutions. The first step is to iteratively create each possible combination of source proportions (that sum to $100 \%$ ) by some small increment (hereafter referred to as "source increment"), such as $1 \%$ or $2 \%$. Second, the predicted isotopic signatures for the mixture are computed as each combination is created. Third, these predicted mixture signatures are compared with the observed mixture signatures. If they are equal, or within some small mass balance tolerance, such as $\pm 0.1 \%$, this combination of source proportions represents a feasible solution and is stored in a data set. Lastly, the distribution of all such feasible solutions in the data set is described. To perform these procedures a Visual Basic program called IsoSource was created The user supplies the isotopic signatures of the sources and the mixture, along with the desired source increment and the mass balance tolerance. Output files include all the feasible source combinations, with histograms and descriptive statistics on the distributions for each source. The IsoSource program is available for public use at http:// www.epa.gov/wed/pages/models.htm. To avoid misrepresenting the results, users of this procedure should report the distribution of feasible solutions rather than focusing on a single value such as the mean (Phillips and Gregg, 2003).

Besides general (ecosystem) concepts, ecological traits of some species were specified on the basis of stable isotope analyses. Using the $\delta^{13} \mathrm{C}$-based isotope mixing model, described above, Kanaya et al. (2009) found that Carassius carassius, Carassius auratus gibelio and Abramis brama in Chany Lake depended mostly on microalgal production (phytoplankton and/ or epiphytes, 61-98\%), while Cyprinus carpio, 
Leuciscus idus and Rutilus rutilus depended more on riparian and/or macrophytic production (50$80 \%$ on average). In Northern California rivers it was found that pool-dwelling predatory fish, spined sticklebacks Gasterosteus aculeatus and minnow Hesperoleucas symmetricus had heavy reliance on prey derived from local pool primary production and not on production imported from faster flowing habitats (Finlay et al., 1999). In coastal lakes in British Columbia although Daphnia and calanoid copepods both were omnivores, the calanoids were an average of 0.74 trophic levels higher than Daphnia (Matthews and Mazumder, 2003). In St. Lawrence River estuary, free bacteria had very similar $\delta^{13} \mathrm{C}$ to that of dissolved organic carbon, whereas the $\delta^{13} \mathrm{C}$ of aggregate bacteria was about $4 \%$ lower and very close to that of the $<10-\mu \mathrm{m}$ and $10-64-\mu \mathrm{m}$ seston fractions (Barnard et al., 2006). The cited authors also determined trophic position of invasive zebra mussel veligers and found out, that despite their high abundance in the estuary veligers did not share resources with native zooplankton and did not serve as important carbon sources for higher trophic levels fish larvae. Although cyanobacteria are generally regarded as a poor food source, stable isotope analysis indicated that freshwater shrimp Paratya australiensis derive a substantial portion (up to $69 \%$ ) of their organic carbon requirements from benthic cyanobacterial accumulations (Piola et al., 2008). The mean $\delta^{15} \mathrm{~N}$ in eggs of pheasanttailed jacana (Hydrophasianus chirurgus) from
Haleji Lake (Pakistan) was about $2.6 \%$ lower than in eggs of little cormorant (Phalacrocorax niger). This difference indicates that jacanas are about one trophic level lower than fish predator little cormorant and probably behaving like omnivores, taking variable proportions of plants and invertebrates (Ramirez et al., 2009).

\section{Conclusion}

Thus, stable isotopes are becoming a standard analytical tool in food web ecology. Careful use must be made of this tool, however. In particular, ${ }^{13} \mathrm{C} /{ }^{12} \mathrm{C}$ and ${ }^{15} \mathrm{~N} /{ }^{14} \mathrm{~N}$ ratios appear to be most useful for identifying trophic relationships. Ratios of some other isotopes, such as sulfur $\delta^{34} \mathrm{~S}$, in general cannot be used for the tracing of trophic webs, because they don't have distinct patterns of distribution between organisms of different trophic levels (Fry, 1988). Nevertheless, $\delta \mathrm{D}(\delta$ ${ }^{2} \mathrm{H} /{ }^{1} \mathrm{H}$ ) may prove a powerful complement to those based on $\delta^{13} \mathrm{C}$ for distinguishing allochthonous and autochthonous sources of energy for higher trophic levels in aquatic ecosystems. For instance, in streams in the southwestern United States tissue $\delta \mathrm{D}$ for allochthonous primary producers ranged from -125 to $-162 \%$, whereas $\delta \mathrm{D}$ of autochthonous primary producers was far lower, ranging from -214 to $-292 \%$ (Doucett et al., 2007). Following development of stable technique and careful taking into account limitations of this method will provide substantial progress of our knowledge in environmental sciences.

\section{References}

Akerblom N., Goedkoop W. (2003) Stable isotopes and fatty acids reveal that Chironomus riparius feeds selectively on added food in standardized toxicity tests. Environmental Toxicology and Chemistry 22: 1473-1480.

Barnard C., Martineau C., Frenette J.-J., Dodson J.J., Vincent W.F. (2006) Trophic position of zebra mussel veligers and their use of dissolved organic carbon. Limnol. Oceanogr. 51: 1473-1484.

Beaudoin C.P., Tonn W.M., Prepas E.E., Wassenaar L.I. (1999) Individual specialization and trophic adaptability of northern pike (Esox lucius): an isotope and dietary analysis. Oecologia 120: 386-396. 
Borderelle A.-L., Gilmette C., Lovy C., Gerdeaux D., Verneaux V. (2008) Macroinvertebrate $\delta 13 \mathrm{C}$ variability analysis for the assessment of lake trophic functioning. Fundamental and Applied Limnology 172: 289-300.

Boschker H.T.S., Kromkamp J.C., Middelburg J.J. (2005) Biomarker and carbon isotopic constraints on bacterial and algal community structure and functioning in a turbid, tidal estuary. Limnol. Oceanogr. 50: 70-80.

Budge S.M., Wooller M.J., Springer A.M., Iverson S.J., McRoy C.P., Divoky G.J. (2008) Tracing carbon flow in an arctic marine food web using fatty acid-stable isotope analysis. Oecologia 157:117-129.

Canuel E.A., Cloern J.E., Ringelberg D.B., Guckert J.B., Rau G.H. (1995) Molecular and isotopic tracers used to examine sources of organic matter and its incorporation into the food webs of San Francisco Bay. Limnol. Oceanogr. 40: 67-81.

Cole J.J., Carpenter S.R., Kitchell J.F., Pace M.L. (2002) Pathways of organic carbon utilization in small lakes: Results from a whole-lake ${ }^{13} \mathrm{C}$ addition and coupled model. Limnol. Oceanogr. 47: $1664-1675$.

Cole J.J., Carpenter S.R., Pace M.L., Van de Bogert M.C., Kitchell J.L., Hodgson J.R. (2006) Differential support of lake food webs by three types of terrestrial organic carbon. Ecology Letters 9: $558-568$.

DeNiro M.J., Epstein S. (1977) Mechanism of carbon isotope fractionation associated with lipid synthesis. Science 197: 261-263.

Doucett R.R., Marks J.C., Blinn D.W., Caron M., Hungate B.A. (2007) Measuring terrestrial subsidies to aquatic food webs using stable isotopes of hydrogen. Ecology 88: 1587-1592.

Fantle M.S., Dittel A.I., Schwalm S.M., Epifanio C.E., Fogel M.L. (1999) A food web analysis of the juvenile blue crab, Callinectes sapidus, using stable isotopes in whole animals and individual amino acids. Oecologia 120:416-426.

Finlay J.C. (2001) Stable-carbon-isotope ratios of river biota: implications for energy flow in lotic food webs. Ecology 82: 1052-1064.

Finlay J.C. (2004) Patterns and controls of lotic algal stable carbon isotope ratios. Limnol. Oceanogr. 49: 850-861.

Finlay J.C., Power M.E., Cabana G. (1999) Effects of water velocity on algal carbon isotope ratios: Implications for river food web studies. Limnol. Oceanogr. 44: 1198-1203.

Fry B. (1988) Food web structure on Georges Bank from stable C, N, and S isotopic compositions. Limnol. Oceanogr. 33: 1182-1 190.

Fry B., Ewel K.C. (2003) Using stable isotopes in mangrove fisheries research - a review and outlook. Isotopes in Environmental and Health Studies 39: 191-196.

Füreder L., Welter C., Jackson J.K. (2003) Dietary and stable isotope $\left(\delta^{13} \mathrm{C}, \delta^{15} \mathrm{~N}\right)$ analyses in alpine stream insects. Internat. Rev. Hydrobiol. 88: 314-331.

Gentsch E., Kreibich T., Hagen W., Niehoff B. (2009) Dietary shifts in the copepod Temora longicornis during spring: evidence from stable isotope signatures, fatty acid biomarkers and feeding experiments. Journal of Plankton Research 31:45-60.

Goedkoop W., Akerblom N., Demandt M.H. (2006) Trophic fractionation of carbon and nitrogen stable isotopes in Chironomus riparius reared on food of aquatic and terrestrial origin. Freshwater Biology 51: 878-886. 
Grey J., Kelly A., Jones R.I. (2004) High intraspecific variability in carbon and nitrogen stable isotope ratios of lake chironomid larvae. Limnol. Oceanogr. 49: 239-244.

$\mathrm{Gu}$ B. (2009) Variations and controls of nitrogen stable isotopes in particulate organic matter of lakes. Oecologia 160:421-431.

Gu B., Chapman A.D., Schelske C.L. (2006) Factors controlling seasonal variations in stable isotope composition of particulate organic matter in a soft water eutrophic lake. Limnol. Oceanogr. 51: 2837-2848.

Hobson K.A. (1999) Tracing origins and migration of wildlife using stable isotopes: a review. Oecologia 120: 314-326.

Kanaya G., Yadrenkina E.N., Zuykova E.I., Kikuchi E., Doi H., Shikano S., Mizota C., Yurlova N.I. (2009) Contribution of organic matter sources to cyprinid fishes in the Chany Lake - Kargat River estuary, western Siberia. Marine and Freshwater Research 60: 510-518.

Karlsson J. (2007) Different carbon support for respiration and secondary production in unproductive lakes. Oikos 116: 1691-1696.

Keough J.R., Sierszen M.E., Hagley C.A. (1996) Analysis of a Lake Superior coastal food web with stable isotope techniques. Limnol. Oceanogr. 41: 136-146.

Lancaster J., Bradley D.C., Hogan A., Waldron S. (2005) Intraguild omnivory in predatory stream insects. Journal of Animal Ecology 74: 619-629.

Lancaster L., Waldron S. (2001) Stable isotope values of lotic invertebrates: Sources of variation, experimental design, and statistical interpretation. Limnol. Oceanogr. 46: 723-730.

Lau D.C.P., Leung K.M.Y., Dudgeon D. (2009) What does stable isotope analysis reveal about trophic relationships and the relative importance of allochthonous and autochthonous resources in tropical streams? A synthetic study from Hong Kong. Freshwater Biology 54: 127-141.

Mateo M.A., Serrano O.,Serrano L., Michener R.H. (2008) Effects of sample preparation on stable isotope ratios of carbon and nitrogen in marine invertebrates: implications for food web studies using stable isotopes. Oecologia 157: 105-115.

Matthews B., Mazumder A. (2003) Compositional and interlake variability of zooplankton affect baseline stable isotope signatures. Limnol. Oceanogr. 48: 1977-1987.

Mulholland P.J., Tank J.L., Sanzone D.M., Wollheim W.M., Peterson B.J., Webster J.R., Meyer J.L. (2000) Food resources of stream macroinvertebrates determined by natural-abundance stable C and $\mathrm{N}$ isotopes and $\mathrm{a}^{15} \mathrm{~N}$ tracer addition. J. N. Am. Benthol. Soc. 19: 145-157.

Nilsen M., Pedersen T., Nilssen E.M., Fredriksen S. (2008) Trophic studies in a high-latitude fjord ecosystem - a comparison of stable isotope analyses $\left(\delta^{13} \mathrm{C}\right.$ and $\left.\delta^{15} \mathrm{~N}\right)$ and trophic-level estimates from a mass-balance model. Can. J. Fish. Aquat. Sci. 65: 2791-2806.

O’Reilly C.M., Hecky R.E., Cohen A.S., Plisnier P.-D. (2002) Interpreting stable isotopes in food webs: Recognizing the role of time averaging at different trophic levels. Limnol. Oceanogr. 47: 306309.

Pel R., Hoogveld H., Floris V. (2003) Using the hidden isotopic heterogeneity in phyto- and zooplankton to unmask disparity in trophic carbon transfer. Limnol. Oceanogr. 48: 2200-2207.

Perga M.-E., Kainz M., Matthews B., Mazumder A. (2006) Carbon pathways to zooplankton: insights from the combined use of stable isotope and fatty acid biomarkers. Freshwater Biology 51: 2041-2051. 
Persaud A.D., Dillon P.J., Lasenby D., Yan N.D. (2009) Stable isotope variability of mesozooplankton along a gradient of dissolved organic carbon. Freshwater Biology 54: 1705-1719.

Peterson B.J., Fry B. (1987) Stable isotopes in ecosystem studies. Ann. Rev. Ecol. Syst. 18: 293320.

Peterson B., Fry B., Deegan L., Hershey A. (1993) The trophic significance of epilithic algal production in a fertilized tundra river ecosystem. Limnol. Oceanogr. 38: 872-878.

Phillips D.L., Gregg J.W. (2003) Source partitioning using stable isotopes: coping with too many sources. Oecologia 136: 261-269.

Piola R.F., Suthers I.M., Rissik D. (2008) Carbon and nitrogen stable isotope analysis indicates freshwater shrimp Paratya australiensis Kemp, 1917 (Atyidae) assimilate cyanobacterial accumulations. Hydrobiologia 608: 121-132.

Pond D.W., Leakey R.J.G., Fallick A.E. (2006) Monitoring microbial predator-prey interactions: an experimental study using fatty acid biomarker and compound-specific stable isotope techniques. Journal of Plankton Research 28: 419-427.

Ramirez F., Jover L., Sanpera C., Ruiz X., Pique E., Guitart R. (2009) Combined measurements of egg fatty acids and stable isotopes as indicators of feeding ecology in lake-dwelling birds. Freshwater Biology 54: 1832-1842.

Schmidt T.C., Zwank L., Elsner M., Berg M., Meckenstock R.U., Haderlein S.B. (2004) Compoundspecific stable isotope analysis of organic contaminants in natural environments: a critical review of the state of the art, prospects, and future challenges. Anal. Bioanal. Chem. 378: 283-300.

Smyntek P.M., Teece M.A., Schulz K.L., Thackeray S.J. (2007) A standard protocol for stable isotope analysis of zooplankton in aquatic food web research using mass balance correction models. Limnol. Oceanogr. 52: 2135-2146.

Syväranta J., Tiirola M., Jones R.I. (2008) Seasonality in lake pelagic $\delta 15 \mathrm{~N}$ values: patterns, possible explanations, and implications for food web baselines. Fundamental and Applied Limnology 172: $255-262$.

Van den Meersche K., Van Rijswijk P., Soetaert K., Middelburg J.J. (2009) Autochthonous and allochthonous contributions to mesozooplankton diet in a tidal river and estuary: Integrating carbon isotope and fatty acid constraints. Limnol. Oceanogr. 54: 62-74.

Vanderklift M.A., Ponsard S. (2003) Sources of variation in consumer-diet $\delta^{15} \mathrm{~N}$ enrichment: a meta-analysis. Oecologia 136:169-182.

Vander Zanden M.J., Rasmussen J.B. (2001) Variation in $\delta^{15} \mathrm{~N}$ and $\delta^{13} \mathrm{C}$ trophic fractionation: Implications for aquatic food web studies. Limnol. Oceanogr. 46: 2061-2066.

Ventura M., Jeppesen E. (2009) Effects of fixation on freshwater invertebrate carbon and nitrogen isotope composition and its arithmetic correction. Hydrobiologia 632: 297-308.

Ventura M., Catalan J. (2008) Incorporating life histories and diet quality in stable isotope interpretations of crustacean zooplankton. Freshwater Biology 53: 1453-1469.

Vuorio K., Tarvainen M., Sarvala J. (2007) Unionid mussels as stable isotope baseline indicators for long-lived secondary consumers in pelagic food web comparisons. Fundamental and Applied Limnology 169: 237-245.

Wada E. (2009) Stable $\delta^{15} \mathrm{~N}$ and $\delta^{13} \mathrm{C}$ isotope ratios in aquatic ecosystems. Proc. Jpn. Acad., Ser. B. 85: 98-107. 


\title{
Анализ стабильных изотопов в водной экологии (обзор)
}

\section{М.И. Гладышев}

Институт биофизики Сибирского отделения Российской академии наук Россия 660036, Красноярск, Академгородок, 50

Сибирский федеральныий университет Россия 660041, Красноярск, пр. Свободный, 79

\begin{abstract}
На основе публикаций преимущественно последнего десятилетия рассмотрена теория $и$ практика анализа стабильных изотопов углерода и азота в трофических исследованиях водных экосистем. Описаны методы измерения соотношений стабильных изотопов, $\delta^{13} \mathrm{C} u$ $\delta^{15} N$, включая анализ изотопов в отдельных классах вещуеств. Обобщены данные о различиях изотопного состава водных и наземных организмов, а также разнообразных видов ижизненных форм в основных типах местообитаний. Рассмотрено трофическое фракиионирование ${ }^{15} \mathrm{~N}$ как основа для количественной оценки трофической позиции организмов. Рассмотрень экологические факторы, влияющие на соотношения изотопов, а также приведены сведения об ограничениях метода анализа стабильных изотопов. Перечислень новейшие концепции водной экологии, разработанные на базе применения анализа стабильных изотопов. Сделан вывод, что анализ стабильных изотопов становится стандартным инструментом для экологических исследований пищевых сетей. Тем не менее, использование этого инструмента требует большой осторожности.
\end{abstract}

Ключевые слова: стабильные изотопь; водные экосистемы; трофическое фракционирование; трофическая позиция 